\title{
Pengaruh Pendidikan Matematika Realistik Terhadap Hasil Belajar Matematika Siswa dengan Pengendalian Kemampuan Numerik
}

\author{
I Nengah Purna ${ }^{1 *}$, I Made Ardana ${ }^{2}$, Nyoman Dantes $^{3}$ iD \\ 1,2,3 Program Studi Pendidikan Dasar, Program Pascasarjana, Universitas Pendidikan Ganesha, Singaraja, Indonesia \\ *Corresponding author: nengah.purnal@pasca.undiksha.ac.id
}

\begin{abstract}
Abstrak
Rendahnya hasil belajar matematika salah satu penyebabnya adalah sikap negatif siswa terhadap matematika. Penelitian ini bertujuan untuk menganalis pengaruh penerapan pendidikan matematika realistik terhadap hasil belajar matematika pada siswa dengan pengendalian kemampuan numerik. Desain penelitian ini menggunakan desain Single Factor Independent groups design with use of covariate dengan kovariabel kemampuan numerik. Populasi dalam penelitian ini berjumlah 168 orang siswa. Sampel penelitian berjumlah 72 orang siswa yang ditentukan dengan tehnik random sampling. Metode pengumpulan data menggunakan metode tes. Teknik analisi data menggunakan Anava satu jalan, Anakova dan Product Moment. Hasil Penelitian menunjukkan bahwa terdapat pengaruh penerapan pendidikan matematika realistik terhadap hasil belajar matematika siswa (Fhitung 9,145 > Ftabel = 3,98, p <0,05), setelah kovariabel kemampuan numerik dikendalikan, terdapat pengaruh penerapan pendidikan matematika realistik terhadap hasil belajar matematika siswa (Fhitung sebesar $42,797>$ Ftabel $=3,98, p<0,05$ ), dan terdapat kontribusi yang signifikan antara kemampuan numerik dengan hasil belajar matematika siswa sebesar 81,36\%. Berdasarkan hasil temuan dapat disimpulkan bahwa penerapan PMR berpengaruh terhadap hasil belajar matematika siswa kelas V SD baik sebelum maupun setelah dikendalikan kemampuan numerik siswa.
\end{abstract}

Kata kunci: Hasil Belajar, Kemampuan Numerik, PMRI

\section{Abstract}

One of the causes of low mathematics learning outcomes is the negative attitude of students towards mathematics. This study aims to analyze the effect of applying realistic mathematics education on mathematics learning outcomes in students with numerical control abilities. The design of this study uses a Single Factor Independent groups design with use of covariate with numerical ability covariable. The population in this study amounted to 168 students. The research sample amounted to 72 students who were determined by random sampling technique. Methods of data collection using the test method. The data analysis technique uses one-way Anova, Ananova and Product Moment. The results showed that there was an effect of applying realistic mathematics education on students' mathematics learning outcomes (Fcount $9.145>$ Ftable $=$ 3.98, $p<0.05)$, after the numerical ability covariable was controlled, there was an effect of applying realistic mathematics education to students' mathematics learning outcomes ( Fcount of $42.797>$ Ftable $=3.98, p<0.05$ ), and there is a significant contribution between numerical ability and students' mathematics learning outcomes of $81,36 \%$. Based on the findings, it can be concluded that the application of PMR affects the mathematics learning outcomes of fifth grade elementary school students both before and after being controlled by students' numerical abilities.

Keywords: Learning Outcomes, Numerical Ability, PMRI

$\begin{array}{ll}\text { History: } & \\ \text { Received } & : 20 \text { November } 2020 \\ \text { Revised } & : 15 \text { Desember } 2020 \\ \text { Accepted } & : 15 \text { Februari } 2021 \\ \text { Published } & : 25 \text { Maret } 2021\end{array}$

\section{Pendahuluan}

Matematika merupakan ilmu universal yang mendasari perkembangan teknologi modern yang mempunyai peran penting dalam berbagai disiplin dan memajukan daya pikir 
manusia (L.E., 2018). Perkembangan teknologi informasi dan kemunikasi dilandasi oleh perkembangan matematika di bidang teori bilangan, aljabar, analisis, teori peluang dan matematika diskrit (Ikhsan \& Munzir, 2019). Untuk menguasai dan menciptakan teknologi di masa depan diperlukan penguasaan matematika yang kuat sejak dini. Matematika perlu diberikan kepada seluruh siswa mulai dari sekolah dasar untuk membekali siswa dengan kemampuan berpikir logis, analitis, sistematis, kritis, dan kreatif, serta kemampuan bekerjasama (Abdul Karim et al., 2020; Fajriah \& Asiskawati, 2015). Kompetensi tersebut diperlukan agar siswa dapat memiliki kemampuan memperoleh, mengelola dan memanfaatkan informasi untuk bertahan hidup pada keadaan yang selalu berubah, tidak pasti, dan kompetitif. Tuntutan dalam pembelajaran matematika tertuang dalam standar kompetensi lulusan untuk mata pelajaran matematika SD/MI memahami konsep materi serta menggunakannya dalam pemecahan masalah kehidupan sehari-hari, memiliki sikap menghargai matematika serta kegunaannya dalam kehidupan dan memiliki kemampuan berpikir logis, krits dan kreatif (Crismono, 2017; Soekisno, 2015). Pemahaman konsep sangatlah penting agar peserta didik tidak mengalami kesulitan dalam belajar.

Realita yang terjadi di lapangan, secara teori pengetahuan matematika harus dikonstruksi sehingga akibatnya pembelajaran matematika harus memberikan kesempatan kepada siswa untuk mengkonstruksi konsep yang ada. Rendahnya hasil belajar matematika salah satu penyebabnya adalah sikap negatif siswa terhadap matematika (Lestari et al., 2018). Berdasarkan hasil observasi terhadap pembelajaran matematika di Kelas V pada SD Gugus IV Kecamatan Kubu Kabupaten Karangasem, diperoleh data sebagai berikut. 1) Hasil belajar matematika rendah; 2) Pembelajaran belum melatih daya pikir/logika siswa. Karena latihan soal yang diberikan kepada siswa masih berada pada tingkat C1. Serta lebih mengutamakan soal objektif; 3) Siswa kurang percaya diri dalam menyelesaikan persoalan matematika, bahkan siswa terlihat tidak paham ketika mengerjakan soal cerita; 4) Materi pembelajaran belum realistik sehingga tidak sesuai dengan tahap berpikir siswa sekolah dasar yaitu operasional kongkrit; 5) Pembelajaran yang dilakukan belum memberikan kesempatan kepada siswa untuk mengkonstruksi konsep yang sedang dipelajari; 6) Pembelajaran yang dilakukan oleh guru belum inovatif serta 7) Penggunaan media belajar atau masalah yang konkret sangat jarang ditemukan.

Rendahnya hasil belajar matematika siswa dapat disebabkan oleh banyak faktor, di antaranya faktor eksternal dan internal. Faktor eksternal meliputi sarana dan prasarana, kurikulum serta lingkungan. Sedangkan faktor internal meliputi bakat, motivasi, kemampuan kognitif/akademik, minat, serta fisik dan psikis siswa. Salah satu jenis kemampuan akademik yang mempunyai peranan untuk meningkatkan hasil belajar yaitu kemampuan numerik (matematis-logis). Kemampuan numerik merupakan kemampuan yang berkaitan dengan kecermatan dan kecepatan dalam penggunaan fungsi-fungsi hitung serta berhubungan dengan operasi hitung bilangan (Gunur et al., 2018; Irawan, 2016). Siswa akan mengalami kesulitan dalam belajar matematika apabila tidak mempunyai kemampuan numerik, selain itu dengan kemampuan numerik yang baik mampu mengelola logika dan melibatkan proses berpikir logis, berhitung, menyusun pola hubungan, serta memecahkan masalah (Achdiyat \& Utomo, 2018; Gunur, B. \& Ardana, 2016).

Untuk mengatasi permasalahan tersebut diperlukan adanya upaya untuk meningkatkan daya nalar matematis siswa dan kemampuan numerik. Belajar matematika merupakan kegiatan mental yang tinggi, harus dilakukan secara berurutan, kontinu, menggunakan pengalaman belajar sebelumnya, lebih mengutamakan pengertian dari pada hafalan dan harus mengkonstruksi sendiri pengetahuannya melalui kegiatan aktif dalam belajar (Munawarah et al., 2013). Prinsip dari pembelajaran matematika yaitu siswa mengawali pembelajaran dari memahami, berpartisipasi aktif dalam membangun pengetahuan baru berdasarkan pengalaman dan pengetahuan sendiri yang dibangun dari 
pengetahuan yang diperoleh sebelumnya (Agusta, 2020). Sedangkan hasil belajar matematika merupakan perubahan prilaku yang terjadi baik dari kognitif, sikap maupun psikomotor dalam memecahkan permasalahan yang terkait dengan permasalahan matematika (Rahayu \& Hidayati, 2018). Perubahan prilaku tersebut meliputi sikap kritis, objektif, analitis, logis, kreatif, percaya diri dalam memecahkan masalah. Faktor ekstern yang dimaksud salah satunya adalah pendekatan pembelajaran dalam hal ini adalah penerapan PMR (Nugraheni, 2013).

Pendidikan Matematika Realistik adalah salah satu pendekatan belajar matematika yang dikembangkan untuk mendekatkan matematika kepada siswa (Puspitasari \& Airlanda, 2021; Zaini \& Marsigit, 2014). Pendekatan pembelajaran ini yang bertolak dari hal-hal yang nyata bagi siswa, menekankan keterampilan proses, berdiskusi dan berkolaborasi, berargumentasi dengan teman sekelas sehingga mereka dapat menemukan sendiri (student inventing) sebagai kebalikan dari teacher telling) dan pada akhirnya menggunakan matematika itu untuk menyelesaikan masalah baik secara individu maupun kelompok. PMR memiliki kelebihan antara lain membangun sendiri pengetahuannya, sehingga dapat mengingat materi, suasana dalam proses pembelajaran menyenangkan karena menggunakan realitas kehidupan, sehingga siswa tidak mudah bosan untuk belajar matematika, siswa merasa dihargai dan semakin terbuka, menumbuhkan kerjasama dan mendidik karakter siswa serta melatih siswa berpikir kritis melalui kemampuan numerik (Gunur, B. \& Ardana, 2016).

Ada beberapa temuan penelitian yang relevan yang terkait dengan pendidikan matematika realistic. Terdapat pengaruh pendidikan matematika realistik Indonesia terhadap pemahaman konsep siswa pada materi (Sari, 2015). Pendekatan PMRI juga memengaruhi hasil belajar siswa (Faot \& Amin, 2020). Pembelajaran pendekatan matematika realistik lebih baik dari pembelajaran konvensional ditinjau dari kemampuan penalaran dan komunikasi matematika siswa (Zaini \& Marsigit, 2014). Pendekatan PMRI efektif diterapkan terlihat dari motivasi berprestasi, tapi tidak efektif ditinjau dari kemampuan pemecahan masalah, dan prestasi belajar siswa (Wahidin \& Sugiman, 2014). Pendekatan PMRI berpengaruh terhadap aktivitas dan pemahaman konsep matematika siswa, dan pendekatan PMRI lebih baik dibandingkan direct instruction ditinjau dari aktivitas dan pemahaman konsep matematika siswa kelas (Nugraheni, 2013). PMR dan kemampuan numerik memberikan pengaruh terhadap hasil belajar matematika. Untuk mengetahui seberapa besar pengaruh dan sumbangannya terhadap hasil belajar matematika perlu dideskripsikan dan dianalisis secara ilmiah. Dalam penelitian ini akan diungkapkan secara empiris Pengaruh Pendidikan Matematika Realistik (PMR) Terhadap Hasil Belajar Matematika Siswa Kelas V SD pada Gugus IV Kecamatan Kubu Kabupaten Karangasem Dengan Pengendalian Kemampuan Numerik.

\section{Metode}

Penelitian ini merupakan penelitian eksperimen. Eksperimen dilakukan pada kelompok belajar (kelas) yang sudah ada karena peneliti tidak mungkin mengubah struktur kelas yang sudah ada. Dengan demikian, penelitian ini dikategorikan sebgai eksperimen semu (quasi eksperimen). Rancangan penelitian ini mengikuti desain penelitian eksperimen Single Factor Independent groups design with use of covariate. Kelompok eksperimen merupakan kelas yang diberikan perlakukan berupa pembelajaran dengan menggunakan pendidikan matematika relistik, sedangkan kelompok control merupakan kelas yang diberikan perlakuan berupa pembelajaran konvensional.

Penelitian ini juga mempertimbangkan variabel kontrol kemampuan numerik siswa yang diduga berpengaruh terhadap variabel bebas model pembelajaran dan variabel terikat berupa hasil belajar matematika. Sebaran siswa pada setiap kelas dilakukan secara merata yaitu terdiri atas siswa yang memiliki kemampuan tinggi, sedang, dan rendah yang di lihat 
dari nilai tes kemampuan numerik siswa. Dalam penelitian ini sampel dipilih dengan menggunakan uji t untuk menentukan kesetaraan kelas dan teknik random sampling dengan undian dan yang diacak adalah kelasnya. Dari proses tersebut hanya dua kelas yang akan dipilih, satu kelas sebagai kelas ekperimen dan satu kelas sebagai kelas kontrol. Setelah itu dilakukan pengundian dan didapatkan SD 3 Tianyar Barat sebagai kelas eksperimen dengan jumlah siswa 36 orang dan SD 6 Tianyar Barat sebagai kelas kontrol dengan jumlah siswa 36 orang. Sehingga sampel berjumlah 72 orang siswa. Data dalam penelitian ini terdiri atas (1) Data hasil belajar matematika siswa yang mengikuti PMR; (2) Data kemampuan numerik siswa yang mengikuti PMR; (3) Data hasil belajar matematika siswa yang mengikuti pembelajaran konvensional; serta (4). Data Kemampuan numerik siswa yang mengikuti pembelajaran konvensional. Berdasarkan jenis data tersebut, maka data dalam penelitian ini dikumpulkan dengan menggunakan metode tes. Untuk mengumpulkan data mengenai kemampuan numerik digunakan tes kemampuan numerik. Sedangkan data mengenai hasil belajar matematika siswa dikumpulkan dengan tes hasil belajar matematika.

Sebelum digunakan, kedua instrumen tersebut diuji validitas dan reliabilitasnya. Untuk menghitung validitas butir tes yang bersifat dikotomi menggunakan formula korelasi Point Biserial, nilai rpbi ini kemudian dibandingkan dengan nilai rtabel. Jika rpbi > rtabel maka butir tersebut valid dan jika sebaliknya berarti tidak valid. Uji reliabilitas instrumen dilakukan secara internal konsistensi yakni mencoba instrumen sekali saja kemudian butir yang telah dinyatakan valid berdasarkan uji validitas dengan Alpha Cronbach. Reliabilitas instrumen yang berbentuk tes pilihan ganda dengan skor 0-1, maka untuk mencari reliabilitasnya dapat digunakan rumus KR-21. Analisis data dalam penelitian ini menggunakan analisis statistik deskriptif dan inferensial. Pengujian hipotesis pada penelitian ini menggunakan uji Manova. Sebelum dianalisis, terlebih dahulu dilakukan uji prasyarat analisis yang meliputi uji normalitas sebaran data, uji homogenitas varians, dan uji linieritas dan keberartian arah regresi. Analisis statistik yang digunakan untuk menguji hipotesis adalah menggunakan anava satu jalur, anakova, serta product moment dengan bantuan SPSSPC 16.0 for Windows.

\section{Hasil dan Pembahasan}

Hasil uji hipotesis pertama telah berhasil menolak hipotesis nol yang menyatakan bahwa tidak terdapat pengaruh penerapan pendidikan matematika realistik terhadap hasil belajar Matematika siswa, dimana hasil uji menunjukkan skor $F_{\text {hitung }}=9,145$ lebih besar dari $\mathrm{F}_{\text {tabel }}=3,98$, dan $\mathrm{p}<0,05$. Dari rata-rata skor hasil belajar Matematika siswa yang mengikuti pendidikan matematika realistik $=19,2$ dan rata-rata skor hasil belajar matematika siswa yang mengikuti pembelajaran konvensional $=16$. Sehingga secara keseluruhan, hasil belajar matematika siswa yang mengikuti pendidikan matematika realistik lebih tinggi daripada pendekatan pembelajaran konvensional. Dari hasil uji hipotesis tersebut mengisyaratkan bahwa pendidikan matematika realistik lebih berpengaruh terhadap hasil belajar matematika.

Hasil uji hipotesis kedua telah berhasil menolak hipotesis nol yang menyatakan setelah kovariabel kemampuan numerik dikendalikan, tidak terdapat pengaruh penerapan PMR terhadap hasil belajar matematika siswa. Hal ini tampak dengan melihat harga $F_{\text {hitung }}$ sebesar 42,797 $>F_{\text {tabel }}=3$,98. serta nilai signifikansi lebih kecil daripada 0,05. Hal ini berarti hipotesis nol (H0) di tolak dan hipotesis 1 (H1) yang menyatakan bahwa "setelah kovariabel kemampuan numerik dikendalikan, terdapat pengaruh penerapan PMR terhadap hasil belajar matematika siswa", diterima. Hasil ini sekaligus membuktikan bahwa hasil belajar matematika siswa yang mengikuti pembelajaran dengan pendekatan matematika realistik memang lebih baik dari siswa yang mengikuti pembelajaran konvensional walaupun terdapat pengontrolan kemampuan numeriknya. 
Tabel 1. Hasil analisis Hasil Belajar dan kemampuan numerik siswa dengan Anacova

\section{Tests of Between-Subjects Effects}

\begin{tabular}{lrrrrr}
\hline \multicolumn{1}{c}{ Dependent Variable:Hasil Belajar } & & & & \\
\hline \multicolumn{1}{c}{ Sumber } & $\begin{array}{c}\text { Jenis III Jumlah } \\
\text { Kuadrat }\end{array}$ & df & $\begin{array}{l}\text { Rata-rata } \\
\text { kuadrat }\end{array}$ & \multicolumn{1}{c}{ F } & Signifikansi \\
\hline Perbaikan & $1406.230^{\mathrm{a}}$ & 2 & 703.115 & 264.498 & $<0,05$ \\
model & 150.672 & 1 & 150.672 & 56.680 & $<0,05$ \\
hambatan & 1222.549 & 1 & 1222.549 & 459.899 & $<0,05$ \\
KOvariabel & 113.766 & 1 & 113.766 & 42.797 & 0,05 \\
Model & 183.423 & 69 & 2.658 & & \\
Pembelajaran & 23815.000 & 72 & & & \\
Error & 1589.653 & 71 & & & \\
Total & & & & \\
Total Perbaikan & & & & & \\
\hline
\end{tabular}

a. R Squared $=, 885$ (Adjusted R Squared $=, 881$ )

Hasil uji hipotesis ke tiga menyatakan bahwa terdapat kontribusi kemampuan numerik terhadap hasil belajar matematika siswa. Kemampuan numerik dalam penelitian ini memberikan kontribusi positif terhadap hasil belajar siswa, besarnya kontribusi kovaribel kemampuan numerik terhadap hasil belajar matematika siswa, ditunjukan dengan melihat

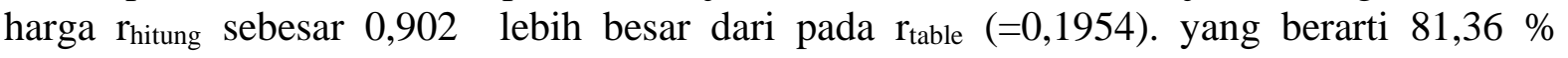
perubahan pada hasil belajar matematika dapat diterangkan oleh kemampuan numerik.

Temuan penelitian pertama, pendidikan matematika realistik lebih berpengaruh terhadap hasil belajar matematika. Pendekatan Matematika Realistik adalah suatu pendekatan pembelajaran matematika yang memiliki karakteristik menggunakan masalah kontekstual, menggunakan pendekatan, menggunakan kontribusi siswa, terjadinya interaksi dalam proses pembelajaran, menggunakan berbagai teori belajar yang relevan, saling terkait, dan terintegrasi dengan topik pembelajaran lainnya (Dewi \& Agustika, 2020). Secara prinsip pendekatan matematika realistik merupakan gabungan pendekatan konstruktivisme dan kontekstual dalam arti memberi kesempatan kepada siswa untuk membentuk (mengkonstruksi) sendiri pemahaman mereka tentang ide dan konsep matematika, melalui penyelesaian masalah dunia nyata (kontekstual). Mengacu pada temuan dan hasil penelitian yang terdahulu, terbukti bahwa pendekatan matematika realistik lebih efektif dibandingkan dengan pembelajaran konvensional. Pendekatan pembelajaran yang dapat memfasilitasi antara dunia anak dengan karakteristik matematika adalah pendidikan matematika realistik. Gambaran umum dari pendekatan matematika realistik yaitu siswa tidak lagi diberikan penjelasan materi secara lengkap oleh guru, melainkan hanya diarahkan pada pemahaman materi berdasarkan pengalaman mereka memecahkan masalah. Guru tidak lagi memaksakan siswa untuk mengikuti cara berpikir yang dimilikinya, tetapi harus memberi kesempatan kepada siswa untuk mengembangkan cara berpikir mereka sesuai dengan potensinya, dan guru hanya berperan membantu serta mengarahkan cara berpikir siswa untuk memahami konsep melalui pertanyaan arahan (bukan memberikan secara langsung).

Mengacu pada hal tersebut, maka terdapat perbedaan pembelajaran matematika realistik dengan pembelajaran secara konvensional. Proses pembelajaran matematika dengan pendekatan matematika realistik lebih menekankan pada keaktifan siswa dalam mencari dan menemukan suatu ide dan konsep matematika melalui eksplorasi masalah nyata, sedangkan pada pembelajaran konvensional siswa lebih pasif karena siswa terbiasa menerima apa saja 
yang diberikan oleh guru tanpa harus berusaha menemukan sendiri konsep-konsep yang sedang dipelajari, sehingga kegiatan pembelajaran menjadi kurang bermakna. Berdasarkan uraian di atas, maka dugaan yang menyatakan bahwa penerapan PMR berpengaruh terhadap hasil belajar Matematika siswa terbukti dalam penelitian ini. Temuan penelitian kedua, hasil belajar matematika siswa yang mengikuti pembelajaran dengan pendekatan matematika realistik memang lebih baik dari siswa yang mengikuti pembelajaran konvensional walaupun terdapat pengontrolan kemampuan numeriknya. Terdapat perbedaan hasil belajar matematika siswa yang mengikuti penerapan pendidikan matematika realistik dan pembelajaran konvensional.

Berdasarkan hasil analisis data dan hasil penelitian yang terdahulu, terbukti bahwa terdapat pengaruh interaksi antara pendekatan pembelajaran dan kemampuan numerik terhadap hasil belajar matematika. Hasil belajar matematika dipengaruhi oleh banyak faktor, baik faktor internal maupun faktor eksternal. Faktor internal merupakan faktor yang berasal dari dalam diri individu, salah satunya adalah kemampuan siswa. Faktor kemampuan siswa besar sekali pengaruhnya terhadap hasil belajar yang dicapai. Seperti yang diungkapkan Clark (dalam Sudjana, 2005: 39) bahwa hasil belajar siswa di sekolah 70\% dipengaruhi oleh kemampuan siswa dan 30\% dipengaruhi oleh lingkungan. Terkait dengan hasil belajar matematika, maka kemampuan yang perlu dipertimbangkan adalah kemampuan numerik. Kemampuan numerik siswa perlu diperhatikan mengingat pelajaran matematika berkaitan dengan pengerjaan operasi hitung, baik itu pengurangan, penjumlahan, perkalian, maupun pembagian. Individu yang memiliki kemampuan numerik tinggi akan memiliki kemampuan pemecahan masalah, mengklasifikasikan dan mengkategorikan informasi, bekerja dengan konsep-konsep abstrak untuk mengetahui hubungan masing-masing, melakukan eksperimen terkontrol, ketertarikan akan peristiwa alam, serta melakukan perhitungan matematika yang kompleks (Gunur, B. \& Ardana, 2016). Dengan adanya kemampuan numerik tinggi, memungkinkan siswa untuk berprestasi dalam bidang matematika. Sedangkan siswa yang memiliki kemampuan numerik rendah akan memiliki kepercayaan diri yang rendah terhadap kemampuannya dalam menyelesaikan tugas-tugasnya.

Temuan penelitian ketiga, kemampuan numerik memang berkontribusi positif terhadap hasil belajar matematika siswa. Semakin tinggi bakat numerik siswa maka akan semakin tinggi pula prestasi belajar matematika, namun sebaliknya semakin rendah bakat numerik siswa,maka akan semakin rendah pula prestasi belajar matematikanya, serta faktor bakat numerik dapat mempengaruhi prestasi belajar matematika siswa. Perbedaan hasil belajar pada setiap siswa dipengaruhi oleh banyak faktor, salah satunya adalah kesesuaian antara kondisi siswa adalah hal ini adalah kemampuan numerik siswa dengan pendekatan pembelajaran yang diterapkan oleh guru. Perbedaan kemampuan numerik yang ada pada diri siswa berpengaruh terhadap cara belajarnya. Apabila pendekatan pembelajaran yang diterapkan tidak sesuai dengan kemampuan siswa, maka prestasi belajanya pun menjadi rendah, begitu pula sebaliknya. Untuk itu, diperlukan suatu pendekatan pembelajaran yang dapat merangsang pola pikir siswa dalam menemukan dan menggali suatu konsep matematika melalui kegiatan belajar yang menarik dan menantang.

Pendekatan pembelajaran yang sesuai dengan hal tersebut adalah PMR . Dalam PMR , siswa dipandang sebagai individu yang memiliki pengetahuan dan pengalaman sebagai interaksinya dengan lingkungan. Siswa dapat mengkonstruksi kembali temuan-temuan dalam bidang matematika melalui eksplorasi berbagai masalah, baik masalah kehidupan sehari-hari maupun masalah matematlika. Dengan melihat esensi dari PMR dan pendekatan pembelajaran konvensional dan dihubungkan dengan ciri-ciri siswa yang memiliki bakat numerik tinggi tampaknya matematika realistik lebih cocok bagi siswa yang memiliki bakat numerik tinggi. Siswa yang memiliki kemampuan numerik yang tinggi, hasil belajar matematika siswa pendekatan pembelajaran matematika realistik lebih baik dibandingkan 
dengan siswa yang mengikuti pembelajaran konvensional (Achdiyat \& Utomo, 2018). Dengan demikian, pada siswa yang memiliki bakat numerik tinggi, hasil belajar matematika siswa yang mengikuti PMR lebih tinggi daripada siswa yang mengikuti pelajaran dengan pendekatan pembelajaran konvensional yang telah terbukti dalam penelitian ini.

Temuan penelitian ini diperkuat bahwa terdapat pengaruh pendidikan matematika realistik Indonesia terhadap pemahaman konsep siswa pada materi (Sari, 2015). Pendekatan PMRI juga memengaruhi hasil belajar siswa (Faot \& Amin, 2020). Pembelajaran pendekatan matematika realistik lebih baik dari pembelajaran konvensional ditinjau dari kemampuan penalaran dan komunikasi matematika siswa (Zaini \& Marsigit, 2014). Pendekatan PMRI efektif diterapkan terlihat dari motivasi berprestasi, tapi tidak efektif ditinjau dari kemampuan pemecahan masalah, dan prestasi belajar siswa (Wahidin \& Sugiman, 2014). Pendekatan PMRI berpengaruh terhadap aktivitas dan pemahaman konsep matematika siswa, dan pendekatan PMRI lebih baik dibandingkan direct instruction ditinjau dari aktivitas dan pemahaman konsep matematika siswa kelas (Nugraheni, 2013).

Berdasarkan hasil temuan dan pembahasan yang telah dipaparkan, penelitian ini memberikan kontribusi pada penelitian pembelajaran matematika di sekolah dasar yang berfokus pada penerapan pendidikan matematika realistik sebagai upaya meningkatkan hasil belajar dengan kemampuan numerik. Selanjutnya, rekomendasi yang dapat diberikan berdasarkan hasil penelitian ini meliputi 1) mendorong peneliti lain untuk mengkaji lebih lanjut pendidikan matematika realistik, dan 2) mengajak para praktisi pendidikan di sekolah dasar untuk meningkatkan hasil belajar melalui penerapan pendidikan matematika realistik ditinjau dari kemampuan numerik siswa

\section{Simpulan}

Berdasarkan hasil pengujian hipotesis dan pembahasan, dapat ditarik simpulan sebagai berikut. Pertama, terdapat pengaruh penerapan PMR terhadap hasil belajar matematika siswa. Kedua, terdapat pengaruh penerapan PMR terhadap hasil belajar matematika siswa setelah kovariabel kemampuan numerik dikendalikan. Ketiga, terdapat kontribusi positif kemampuan numerik terhadap hasil belajar matematika siswa. Berdasarkan temuan-temuan di atas dapat disimpulkan bahwa penerapan pendidikan matematika realistik berpengaruh terhadap hasil belajar matematika siswa baik sebelum maupun setelah dikendalikan. . Dengan demikian pengalaman belajar siswa tidak hanya sekedar pemahaman konsep tentang materi yang diajarkan. Melainkan juga mampu menambah kemampuan numerik siswa. Pembelajaran pendidikan matematika realistic memberi kontribusi baru bagi pengembangan pembelajaran matematika di jenjang pendidikan dasar, sebagai upaya untuk meningkatkan hasil belajar.

\section{Daftar Rujukan}

Abdul Karim, Dini Savitri, \& Hasbullah. (2020). Pengembangan Media Pembelajaran Matematika Berbasis Android Di Kelas 4 Sekolah Dasar. Jurnal Lebesgue : Jurnal Ilmiah Pendidikan Matematika, Matematika Dan Statistika, 1(2), 63-75. https://doi.org/10.46306/lb.v1i2.17.

Achdiyat, M., \& Utomo, R. (2018). Kecerdasan visual-spasial, kemampuan numerik, dan prestasi belajar matematika. Jurnal Ilmiah Pendidikan MIPA, 7(3), 234-245. https://doi.org/10.30998/formatif.v7i3.2234.

Agusta, E. S. (2020). Peningkatan Kemampuan Matematis Siswa Melalui Pendekatan Pendidikan Matematika Realistik. Journal of Mathematics Education, 2(2). https://doi.org/10.15408/ajme.v2i2.17819.

Crismono, P. C. (2017). Pengaruh Outdoor Learning Terhadap Kemampuan Berpikir Kritis Matematis Siswa The Influence Of Outdoor Learning On The Mathematical Critical 
Thinking Skills Of Students. Junal Pendidikan Matematika Dan Sains, 4(2), 106-113. http://journal.uny.ac.id/index.php/jpms Jurnal

Dewi, N. P. W. P., \& Agustika, G. N. S. (2020). Efektivitas Pembelajaran Matematika Melalui Pendekatan Pmri Terhadap Kompetensi Pengetahuan Matematika. Jurnal Penelitian Dan Pengembangan Pendidikan, 4(2), 204. https://doi.org/10.23887/jppp.v4i2.26781.

Fajriah, N., \& Asiskawati, E. (2015). Kemampuan Berpikir Kreatif Siswa dalam Pembelajaran Matematika Menggunakan Pendekatan Pendidikan Matematika Realistik di SMP. EDU-MAT: Jurnal Pendidikan Matematika, 3(2), 157-165. https://doi.org/10.20527/edumat.v3i2.643.

Faot, M. M., \& Amin, S. M. (2020). Pengaruh Pendekatan Pendidikan Matematika Realistik Indonesia (PMRI) Terhadap Hasil Belajar Siswa. MATHEdunesa, 9(1), 55-60. https://doi.org/10.26740/mathedunesa.v9n1.p55-60.

Gunur, B., S., \& Ardana, I. M. (2016). Pengaruh pendidikan matematika realistik terhadap kemampuan pemecahan masalah matematika di tinjau dari kemampuan numerik siswa SMP Negeri 1 Cibal. Jurnal Pendidikan Dan Pembelajaran Matematika Indonesia, 5(1). http://119.252.161.254/ejournal/index.php/JPM/article/view/2129.

Gunur, B., Makur, A. P., \& Ramda, A. H. (2018). Hubungan Antara Kemampuan Numerik Dengan Kemampuan Pemecahan Masalah Matematis Siswa Di Pedesaan. Jurnal $\begin{array}{lllll}\text { Matematika Dan } & 160 .\end{array}$ https://doi.org/10.24252/mapan.2018v6n2a2.

Ikhsan, S. M., \& Munzir, S. (2019). Meningkatkan Kemampuan Representasi dan Pemecahan Masalah Matematis Siswa melalui Pendekatan Problem Posing dalam Pembelajaran Matematika. Jurnal Peluang, 7(1), 127-135. https://doi.org/10.24815/jp.v7i1.13516.

Irawan, A. (2016). Peranan Kemampuan Numerik Dan Verbal Dalam Berpikir Kritis Matematika Pada Tingkat Sekolah Menengah Atas. Jurnal Ilmiah Pendidikan Matematika, Ilmu Matematika Dan Matematika Terapan, 6(2), 121-130. https://doi.org/10.12928/admathedu.v6i2.5443.

L.E., E. P. (2018). Cooperative Learning Dengan Model Tgt (Teams Games Tournament) Materi Bilangan Bulat Bagi Siswa Kelas Iv Sekolah Dasar. Buana Matematika: Jurnal Ilmiah Matematika Dan Pendidikan Matematika, 7(2:), 85-88. https://doi.org/10.36456/buana_matematika.7.2:.1048.85-88.

Lestari, K. S., Dantes, N., \& -, S. (2018). Pengaruh Model Pembelajaran Berbasis Masalah Terhadap Hasil Belajar Matematika Ditinjau Dari Kemampuan Berpikir Kritis Siswa Kelas Iv Sekolah Dasar Di Gugus I Kecamatan Buleleng. PENDASI: Jurnal Pendidikan Dasar Indonesia, 2(1), 1-12. https://doi.org/10.23887/jpdi.v2i1.2686.

Munawarah, Mulbar, U., \& Minggi, I. (2013). Desain Pembelajaran Matematika Realistik Di Kelas V Sd (Studi Pada Sd Inpres 6/75 Kading). Jurnal Matematika Dan Pembelajaran (Mapan), 1(3), 91-109. http://103.55.216.56/index.php/Mapan/article/view/1128.

Nugraheni, E. A. (2013). Pengaruh Pendekatan PMRI terhadap Aktivitas dan Pemahaman Konsep Matematika Siswa SMP. Pythagoras: Jurnal Pendidikan Matematika, 8(1), 101-108. https://doi.org/10.21831/pg.v8i1.8498.

Puspitasari, R. Y., \& Airlanda, G. S. (2021). Meta-Analisis Pengaruh Pendekatan Pendidikan Matematika Realistik (PMR) Terhadap Hasil Belajar Siswa Sekolah Dasar. Jurnal Basicedu, 5(2), 1094-1103. https://doi.org/10.31004/basicedu.v5i2.878 ISSN.

Rahayu, S., \& Hidayati, W. N. (2018). Meningkatkan Hasil Belajar Matematika Melalui Penggunaan Media Bangun Ruang Dan Bangun Datar Pada Siswa Kelas V Sdn Jomin Barat I Kecamatan Kotabaru Kabupaten Karawang. Jurnal Pendidikan Sekolah Dasar, 4(2), 204. https://doi.org/10.30870/jpsd.v4i2.3854. 
Sari, A. P. (2015). Pengaruh Pendidikan Matematika Realistik Indonesia Terhadap Pemahaman Konsep Siswa Pada Materi Untung dan Persentase Untung. Jurnal Pendidikan Matematika, 8(2), 1-9. https://doi.org/10.22342/jpm.8.2.1862.1-19.

Soekisno, R. B. A. (2015). Pembelajaran Berbasis Masalah Untuk Meningkatkan Kemampuan Argumentasi Matematis Mahasiswa. Infinity Journal, 4(2), 120. https://doi.org/10.22460/infinity.v4i2.77.

Wahidin, \& Sugiman. (2014). The Effect of the IRME Approach on the Achievement Motivation , Problem Solving Skills , and Learning Achievement. Pythagoras, 9(1), 99-109. https://doi.org/10.21831/pg.v9i1.9072.

Zaini, A., \& Marsigit, M. (2014). Perbandingan Keefektifan Pembelajaran Matematika Dengan Pendekatan Matematika Realistik Dan Konvensional Ditinjau Dari Kemampuan Penalaran Dan Komunikasi Matematik Siswa. Jurnal Riset Pendidikan Matematika, 1(2), 152. https://doi.org/10.21831/jrpm.v1i2.2672. 